\title{
Turnover Intention Influencing Factors of Employees: An Empirical Work Review
}

\section{Belete $\mathbf{A K}^{*}$}

Department of Management, Wolaita Sodo University, Ethiopia

\begin{abstract}
The prerequisite to leave one's job or organization is the intention to leave that can be referred as turnover intention. It is the thinking and planning of employees to leave their job and organization due to different reasons. Since turnover intention is not explicit; it is difficult to determine the factors these lead to leave one's job and organization. So this conceptual paper tried to summarize different factors affecting turnover intention of employees which are identified by different scholars and researchers. The researcher reviewed varies empirical works focused on the relationship between job satisfaction, job stress, organizational culture, organizational commitment, salary, organizational justice, promotional opportunity, demographic variables, leadership styles, and Organizational Climate.
\end{abstract}

Keywords: Turnover intention; Factors; Employees

\section{Introduction}

To aid their living people will engage in different types of activities, works and organizations. But the length of time that people spent in these things is undeterminable due to different reasons. People will change or leave their work and organization as much as it will be comfortable for them. The prerequisite to leave one's job or organization is the intention to leave that can be referred as turn over intention.

Turnover intention of employees refers the likelihood of an employee to leave the current job he/she are doing [1]. Every organization regardless of its location, size or nature of business has always given a key concern about Employees' turnover intention [2]. According to Kumar [3], turnover is a critical human resource issue in all sectors of the economy which affects productivity, product and service quality, and profitability.

Researchers like Shamsuzzoha and Shumon [4] stated that turnover has proven to be one of the most costly and seemingly intractable human resource challenges confronting by several organizations globally. Jha [5] identified that turnover force the organization to incur a huge costs relating to recruitment and selection, personnel process and induction, training of new personnel and above all, loss of knowledge gained by the employee while on job. For organizations, the turnover of employees means the waste of investment in the selection and training of personnel. Besides, the high rate of employee turnover in an organization adversely affects the motivation of existing personnel; increases the workload and makes work planning difficult. Thus, the resignation of skilled employees, who are considered as human capital, is an important issue that has a negative impact on the efficiency, effectiveness and general performance of an organization [6].

Even though turnover is a cost for an organization, Habib [7] pointed out that a certain level of turnover cannot be avoided, and in fact, it could be beneficial to the organization as new people join organizations with new ideas that in the process enriched the organizational other activities. A healthy turnover rate is always desired by the top management of organizations to ensure healthy innovative growth of organizations. When turnover is too low, fresh blood and new ideas are lacking and an organization can quickly find itself turning into an ageing machine, unable to cope with change [8].

Turnover can also allow an organization to adapt to market changes without going through costly layoffs. Certain organizations accept a relatively moderate level of staff turnover because it keeps the organization dynamic [9]. Some staff turnover has benefits, and can help increase productivity by ensuring better matches between jobs and workers, as well as offering more flexibility to promote and develop valued staff [8].

\section{Review of Related Literature}

Turnover among the employees is one of the biggest challenges for any organization and have far lasting effects. It has been seen as a serious issue especially in the field of human resources management [10]. Wu and Polsaram [11] added that Employee turnover become a major concern for many organizations nowadays and high employee turnover have a devastating effect on a company, especially if the lost employees are high performers.

\section{Turnover intention}

Turnover intention of employees refers the likelihood of an employee to leave the current job he/she are doing [1]. Every organization regardless of its location, size or nature of business has always given a key concern about Employees' turnover intention [2].

\section{Types of turnover}

Turnover can be classifies as voluntary and involuntary turnover. As Perez [12] stated, since turnover is often associated with variables, such as job satisfaction, it is important to distinguish voluntary from involuntary turnover, otherwise the estimation of such a relationship in terms of all leavers will be inaccurate.

When an employee leaves his work and the organization by his or her will the turnover is termed as voluntary turnover. As cited by Perez [12 described that Voluntary turnovers create significant cost, both in terms of direct cost, such as replacement, or in terms of indirect cost,

*Corresponding author: Belete AK, Department of Management, Wolaita Sodo University, Ethiopia, Tel: 0465514586; E-mail: alubelk@gmail.com

Recieved September 05, 2018; Accepted November 23, 2018; Published November 30, 2018

Citation: Belete AK (2018) Turnover Intention Influencing Factors of Employees: An Empirical Work Review. J Entrepren Organiz Manag 7: 253. doi: 10.4172/2169026X.1000253

Copyright: (C) 2018 Belete AK. This is an open-access article distributed under the terms of the Creative Commons Attribution License, which permits unrestricted use, distribution, and reproduction in any medium, provided the original author and source are credited. 
such as the pressure on remaining staff or the loss of social capital.

Taylor [13] further divided Voluntary turnovers in to functional and dysfunctional turnovers. Functional turnovers are the resignation of substandard performers and dysfunctional turnovers refer to the exit of effective performers. Dysfunctional turnover further classified into avoidable turnover (caused by lower compensation, poor working condition, etc.) and unavoidable turnovers (like family moves, serious illness, death, etc.) over which the organization has little or no influence. Involuntary turnover refers the decision of management to force the employee to leave the organization.

\section{Factors affecting turnover intention}

Turnover may be caused by different factors. These factors of turnover intentions are different from organization to organization to some extent [14]. Jha stated that no single factor can be attributed to turnover intentions and proposed to follow a holistic approach in studying factors affecting turnover intention of employees [5].

Leadership styles: Griffin and Moorhead [15] defined leadership as it is both a process and a property. As a process, leadership involves the use of non-coercive influence. As a property, leadership is the set of characteristics attributed to someone who is perceived to use influence successfully. When we tried to discuss about leadership, we have to consider the leadership styles. Leadership style is the way and manner in which a manager or supervisor chooses to act towards his employees or subordinates and the way the leadership function is being carried out by them. A leadership style is the approach used by managers to exercise their leadership function [16]. Leadership style is said to be a particular behavior applied by a leader to motivate his or her subordinates to achieve the objectives of the organization [17].

In this global competitive environment, effective leadership style is necessary to reduce the attrition rate [18]. As Siew [19] explained that leadership styles have a very strong relationship with turnover intention. Puni et al. [20] found employees under autocratic leaders are more prone to intentions to quit job mainly as a result of the leaders over emphasis on production than people. Workers under democratic leadership style are less likely to involve in turnover intentions due to the collective decision-making approach of the leader.

While Long [2] and Gul et al. [21] found negative insignificant association between turnover intentions and transactional and transformational leadership styles, Siew [19] demonstrated a significant relationship between transformational and transactional leadership style and turnover intention within a study conducted on SMEs in Malaysia.

Demographic variables: Kaya and Abdioğlu [6] described demographic variables, such as age, professional experience (tenure), marital status, professional title and previous knowledge about the profession have no effect on the probability of turnover intention. But, Chowdhury [22], Emiroğlu et al. [23] and Victoria and Olalekan [24] identified that the demographic factors such as age, marital status, tenure, wage, position, and working department are determinants for turnover intention.

Even though Kaya and Abdioğlu [6] found significant relationship between gender and turnover intention Victoria and Olalekan [24] concluded as gender had no significant influence on the intention of employees to leave.

Choong et al. [25] identified significant differences between gender, age group and marital status toward turnover intention, such as female has higher intention to leave as compared to male, while married respondents have higher job commitment as compared to single respondents and elders are willing to retain in their respective institutions as compared to those younger.

Organizational commitment: As defined by Mowday et al. [26] organizational commitment is a strong belief in and acceptance of the organization's goals and values; a willingness to exert considerable effort on behalf of the organization; and a strong desire to maintain membership in the organization. Lambert [27] stated that organizational commitment is a psychological attachment of an employee to an organization. As Lin and Chen [28] and $\mathrm{Wu}$ [11] point out, organizational commitment negatively related with employee's turnover intentions. Ahuja et al. [29] indicated that Organizational commitment is the strongest predictor of employee turnover intention. Cave et al. [30] found that Organizational commitment was significantly related to turnover intention.

Organizational justice: Justice is a broad and multifaceted concept associated with nondiscrimination and fair observance of differences within various disciplines [31]. Organizational justice refers to the extent to which employees perceive workplace procedures, interactions and outcomes to be fair in nature [32]. Organizational justice is characterized by different individuals and parties' perception of fairness of behaviors in an organization and their behavioral responses to those perceptions [31]. In order to ensure that employees are satisfied, committed, and loyal, the organization needs to be fair in its systems regarding distributive, procedural, and interactional justice [33].

When we consider the relationship between organizational justice and turnover intention, Aghaei et al. [34], Sokhanvar et al. [31], and Ozturk et al. [32] found that turnover intention have an inverse and significant relationship to organizational justice. The better justice by organization managers, the lower intention to leave among employees, and so more effectiveness, efficiency and better performance of employees [34].

Iyigun and Tamer [35] and Phayoonpu and Mat [36] found a negative and statistically significant relationship between distributive justice, procedural justice and employee turnover intention. Kwai et al. [37] explained that the higher the level of employee's perception towards fairness to the means used to determine outcomes (procedural justice) and fairness of the outcomes employees receive (distributive justice) tended to increase the level of employees' job satisfaction, organizational commitment while reduces turnover intention.

Organizational climate: Thatcher, et al. [38] assesses the effect of organizational climate on the turnover intention in an information technology firm and they confirmed as it has a direct effect on intention to leave the organization. Also Stone et al. [39] point out that as there is a strong link between organizational climate and intention to leave. When we try to see the organizational climate we have to consider organizational culture. The biggest factor in attracting and most importantly retaining key employee is culture [33].

As Alkahtani [33] indicated in his review of existing empirical works, different researches established that discouraging organizational climate negatively affects job satisfaction which in turn may expedite employee turnover.

Promotion opportunities: Mahapatro [40] described promotion as an advancement of employee to a higher post with greater responsibilities and higher salary, better service conditions and thus higher status. 
Promotion opportunities along with organizational commitment, job characteristics, promotion opportunities, pay level and rewards, quality of work life and job satisfaction has negative and significant relationship with turnover intentions [10]. Job satisfaction and promotion opportunities appeared as significant factor affecting turnover intentions [41]. Promotion Speed and Remuneration Growth are the foremost factors that have direct high impact on Employees' Turnover Intentions [42].

As Nyamubarwa [43] indicated promotional opportunity was one of the factors shaping turnover intention along with salaries and conditions of service, job performance, career growth, work environment, job satisfaction, supervisory style, and employee commitment. Perceived career opportunities outside the organization and lack of career advancement opportunities inside organization increase the employee's intentions to leave the organization [44]. If promotion opportunity is mishandled, it leads to discontentment, frustration, skepticism, bickering among the employees and culminates in a high rate of employee turnover [40].

Salary: Employees in different organizations seek to improve their level of income. Therefore, employees in an organization improve their pay level if they obtain a pay increment in their current organization or by joining other organizations which will provide good pay. With regard this stated that organizations pay level has a potentially important direct influence on voluntary turnover. In today's work environment where pay is one of a determinant factor, employees quits current job and accept the job with higher pay opportunity.

Attractive remuneration packages are one of the very important factors of retention because it fulfills the financial and material desires. As Kumar [3] stated the turnover of employees is mainly due to low salary. Pay level and rewards had negative and significant relationship with turnover intension [10].

Organizational culture: Organizational culture reflects the shared and learned values, beliefs, and attitudes of its members [45]. Organizational culture refers to a system of shared meaning held by members that distinguishes the organization from other organizations [46].

Turnover Intention is significantly influenced by Organizational Culture $[47,48]$. Organizational culture is important element which highly influences the employee commitment, job satisfaction and retention. Habib et al. [49]. Organizational culture that provides challenging jobs diminishes employees' absenteeism and withdrawal intentions from the occupation, job, and the organization [50].

Haggalla and Jayatilake [48] identified the relationship between market culture and hierarchy culture and turnover intention was positive whereas the relationship between clean culture and adhocracy culture turnover intention was negative. There is a positive association between authoritarian organizational culture and turnover intention [51]. Consensual culture has negative and strong correlation with turnover rate of employees [52].

Job stress: Jha [5] indicated that Job stress is a major organizational factor that augments quitting intentions of employees which will come from role ambiguity, role-conflict, work-over-load, and work-family conflict, create stress among employees. Hassan [10] found that job stress is the most significant factor influencing turnover intention. Job stress is an important variable which affect turnover intention [53]. On the other hand job stress is an important variable which affect turnover intention.
Job satisfaction: Job satisfaction is the status in which a person is satisfied and glad with the job [53]. Ali [54] and Wu [11] stated that job satisfaction was found to have a significant negative association with turnover intention [55-60]. Also Alkahtani [33] proved that job satisfaction had a relationship with employee's intention to leave their job. Perez [12] found that job satisfaction was strongest significant predictors of future quits [61-83].

\section{Conclusion}

As it is known employees are the most valuable assets of the organizations. So giving concern for them is very indispensable to the organizations. The one thing organizations will do with regard to their employees is to know the turnover intention of employees and the factors leading to it. This can be done through conducting research and reviewing. Therefor this conceptual paper reviewed different empirical works which deals with the factors influencing turnover intention of employees with the purpose of giving clue for scholars, researchers and organizations.

This conceptual paper focused only on ten factors (job satisfaction, job stress, organizational culture, organizational commitment, salary, organizational justice, promotional opportunity, demographic variables, leadership styles, and Organizational Climate) which are common in any type of organizations. But there are other factors also to be considered like perceived organizational support, perceived supervisor support, job autonomy, Employees' benefits, and training and development.

\section{Suggestions for Future Research}

The relationship between the identified factors and turnover intention was proposed by this paper. Therefor future researchers can conduct empirical study and test the proposed relationship. Also re review was conducted on researches done in different types of organizations like Banks, Educational institutions, Hotels, Micro and Small Enterprises, different types of organizational institutions and the like. And a factor that affects turnover intention in one organization will not work on the other organization. So, future researchers can examine the influence of these factors on different types of organizations.

As stated by Alkahtani, some factors might remain as predictors and others might act as mediators or moderators for the main relationship, therefore, this relationship must be rigorously tested using the appropriate analyses. Besides, due to the abundance of research instruments available to gauge the levels of employees' turnover and its predictors, future researchers must take precautionary measures to choose the one that is most valid and reliable.

\section{References}

1. Ngamkroeckjoti C, Ounprechavanit P, Kijboonchoo T (2012) Determinant Factors of Turnover Intention: A case study of Air Conditioning Company in Bangkok, Thailand. International Conference on Trade, Tourism and Management, pp: 21-22.

2. Long CS, Thean LY, Ismail WKW, Jusoh A (2012) Leadership Styles and Employees' Turnover Intention: Exploratory Study of Academic Staff in a Malaysian College. World Appl Sci J 19: 575-581.

3. Kumar RR (2011) Turn Over Issues in the Textile industry in Ethiopia: A Case of Arba Minch Textile Company. African Journal of Marketing Management 3 : $32-44$.

4. Shamsuzzoha AHM, Shumon RH (2013) Employee Turnover-a Study of its Causes and Effects to Different Industries in Bangladesh.

5. Jha S (2009) Determinants of Employee Turnover Intentions: A Review. Management Today 9: 26-33. 
Citation: Belete AK (2018) Turnover Intention Influencing Factors of Employees: An Empirical Work Review. J Entrepren Organiz Manag 7: 253. doi: 10.4172/2169-026X.1000253

Page 4 of 7

6. Kaya H, Abdioğlu H (2010) An Empirical Study on Employee Turnover Tendency. Amme Administration Magazine 4: 141-183.

7. Habib A (2015) Employee Turnover in Banks- Costs and Benefits.

8. Loquercio D, Hammersley M, Emmens B (2006) Understanding and Addressing Staff Turnover in Humanitarian Agencies. Humanitarian Practice Network.

9. Richardson F (2005) How Can International Non-Governmental Organizations' Resourcing and Reward Models Support Wider Humanitarian Impact? Oxfam GB.

10. Hassan R (2014) Factors Influencing Turnover Intention among Technical Employees in Information Technology Organization: A Case of XYZ (M) SDN. BHD. International Journal of Arts and Commerce.

11. Wu X, Polsaram P (2011) Factors Influencing Employee Turnover Intention: The Case of Retail Industry in Bangkok. Thailand.

12. Perez M (2008) Turnover Intent Diploma Thesis. University of Zurich.

13. Taylor S (1998) Employee Resourcing. Cromwell Press. Wiltshire.

14. Ali Shah I, Fakhr Z, Zaman K, Shakil AM (2010) Measuring Push, Pull and Personal Factors Affecting Turnover Intention: A Case of University Teachers in Pakistan. Review of Economic and Business Studies 3: 167-192.

15. Griffin W, Moorhead G (2014) Organizational Behavior: Managing People and Organizations $11^{\text {th }}$ Edition. Cengage Learning, Mason, USA.

16. Armstrong M (2012) Armstrong's Handbook of Management and Leadership for HR: Developing Effective People Skills for Better Leadership and Management. London: Kogan Page.

17. Ng'ethe JM, Namusong GS, Iravo MA (2012) Influence of Leadership Style on Academic Staff Retention in Public Universities in Kenya. International Journal of Business and Social Science 3: 297-302.

18. Nanjundeswaraswamy TS, Swamy DR (2014) Leadership Styles. Advances in Management.

19. Siew K (2017) Analysis of the Relationship between Leadership Styles and Turnover Intention within Small Medium Enterprise in Malaysia. Arts Social Sci J 1: 1-11.

20. Puni A, Agyemang B, Asamoah S (2016) Leadership Styles, Employee Turnover Intentions and Counterproductive Work Behaviors. Int J Innov Res Dev.

21. Gul S, Ahmad B, Rehman SU, Shabir N, Razzaq N (2012) Leadership Styles, Turnover Intentions and the Mediating Role of Organizational Commitment. Information and Knowledge Management.

22. Chowdhury F (2015) Demographic Factors Impacting Employee Turnover in The Private Banking Sector of Bangladesh. International Journal of Business and Management Invention 4: 46-54.

23. Emiroğlu BD, Akova O, Tanrıverd H (2015) The Relationship Between Turnover Intention and Demographic Factors in Hotel Businesses: A Study at Five Star Hotels in Istanbul. Procedia Soc Behav Sci 207: 385-397.

24. Victoria OA, Olalekan U (2016) Effects of Demographic Factors on Employees Intention to Leave in Selected Private Universities in Southwest. Babcock University Publication Portal.

25. Choong YO, Keh CG, Tan YT, Tan CE (2013) Impacts of Demographic Antecedents Toward Turnover Intention Amongst Academic Staff in Malaysian Private Universities. Aust J Basic Appl Sci 7: 46-54

26. Mowday RT, Porter WL, Steers RM (1982) Employee-Organization Linkages: The Psychology of Commitment, Absenteeism, and Turnover. Organizational and occupational psychology.

27. Lambert E (2003) The Impact of Organizational Justice on Correctional Staff. J Crim Justice 31: 155-168

28. Lin CP, Chen MF (2004) Career Commitment as a Moderator of the Relationships Among Procedural Justice, Perceived Organizational Support, Organizational Commitment, and Turnover Intentions. Asia Pacific Management Review 9: 519-538.

29. Ahuja M, et al (2007) IT Road Warriors: Balancing Work-Family Conflict, Job Autonomy and Work Overload to Mitigate Turnover Intentions. MIS Quarterly 31: $1-17$

30. Cave AH, Chung WH, Choi SG (2013) Determining the Factors Affecting Retention of Employees in Taiwanese Electronics' Firms-General Vs.
Repatriated Employees. International Journal of Academic Research in Business and Social Sciences.

31. Sokhanvar M, Hasanpoor E, Hajihashemi S, Kakemam E (2016) The Relationship between Organizational Justice and Turnover Intention: A Survey on Hospital Nurses. Patient Safety and Quality Improvement Journal 4: 358-362.

32. Ozturk M, Eryesil K, Beduk A (2016) The Effect of Organizational Justice on Organizational Cynicism and Turnover Intention: A Research on the Banking Sector. International Journal of Academic Research in Business and Social Sciences 6: 543-551.

33. Alkahtani AH (2015) Investigating Factors that Influence Employees' Turnover Intention: A Review of Existing Empirical Works. International Journal of Business and Management.

34. Aghaei N, Moshiri K, Shahrbanian S (2012) Relationship Between Organizational Justice and Intention to Leave in Employees of Sport and Youth Head Office of Tehran. Eur J Exp Biol 2: 1564-1570.

35. Iyigun O, Tamer I (2012) The Impact of Perceived Organizational Justice on Turnover Intention: Evidence From An International Electronic Chain Store Operating in Turkey. Journal of Global Strategic Management 6: 5-16.

36. Phayoonpun T, Mat N (2014) Organizational Justice and Turnover Intention: The Mediation Role of Job Satisfaction 6: 1-21.

37. Kwai Fatt C, Khin EWS, Heng TN (2010) The Impact of Organizational Justice on Employee's Job Satisfaction: The Malaysian Companies Perspectives. American Journal of Economics and Business Administration 2: 65-72.

38. Thatcher JB, Stepnia LP, Boyle RJ (2003) Turnover of Information Technology Workers: Examining Empirically the Influence of Attitudes, Job Characteristics and External Markets. J Manag Inf Syst 19: 231-261.

39. Stone PW, Larson EL, Mooney-Kane C, Smolowitz J, Lin SX, et al. (2006) Organizational Climate and Intensive Care Unit Nurses' Intention to Leave. Critical Care Medicine 34: 1907-1912.

40. Mahapatro B (2010) Human Resource Management. New Age International.

41. Shah U, Khan J (2015) An Analysis of the Factors Affecting Turnover Intensions: Evidence from Private Sector Universities of Peshawar. Journal of Social and Administrative Sciences.

42. Biswakarma G (2016) Organizational Career Growth and Employees" Turnover Intentions: Empirical Evidence from Nepalese Private Commercia Banks. International Academic Journal of Organizational Behavior and Human Resource Management 3: 10-26.

43. Nyamubarwa W (2013) I Am Considering Leaving Soon - Turnover Intentions of Academic Librarians in Zimbabwe. Journal of Business Administration and Education 4: 76-90.

44. Stahl GK, Chua CH, Caligiuri P, Cerdin JL, Taniguchi M (2009) Predictors of Turnover Intentions in Learning-Driven and Demand-Driven International Assignments: The Role of Repatriation Concerns, Satisfaction with Company Support, and Perceived Career Advancement Opportunities. Hum Resour Manage 48: 89-109.

45. Hellriegel D, Slocum W (2011) Organizational Behavior. Cengage Learning.

46. Robbins S, Judge T (2013) Organizational Behavior (15 ${ }^{\text {th }}$ edn.), Pearson Education

47. Dwivedi S, Kaushik S, Luxmi K (2013) Impact of Organizational Culture on Turnover Intentions in BPO Sector in India. The Indian Journal of Industrial Relations.

48. Haggalla KHYU, Jayatilake LVK (2017) Study on Organizational Culture and Turnover Intention in International Information Technology Firms in Sri Lanka. International Journal of Scientific Research and Innovative Technology 4: 2313-3759.

49. Habib S, Aslam S, Hussain A, Yasmeen S, Ibrahim M (2014) The Impact of Organizational Culture on Job Satisfaction, Employees Commitment and Turn over Intention. Advances in Economics and Business 2: 215-222.

50. Carmeli A (2005) The Relationship between Organizational Culture and Withdrawal Intentions and Behavior. Int J Manpow 26: 177-195.

51. Kim S (2017) Determinants of Employee Turnover Intention: Understanding the Roles of Organizational Justice, Supervisory Justice, Authoritarian Organizational Culture and Organization Employee Relationship Quality Corporate Communications: An International Journal. 22: 308-328. 
Citation: Belete AK (2018) Turnover Intention Influencing Factors of Employees: An Empirical Work Review. J Entrepren Organiz Manag 7: 253. doi: 10.4172/2169-026X.1000253

Page 5 of 7

52. Park JS, Kim TH (2009) Do Types of Organizational Culture Matter in Nurse Job Satisfaction and Turnover Intention? Leadership in Health Services, pp: 20-38.

53. Bashir A, Durrani F (2014) A study on Determinants of Turnover Intention In Pakistan. Journal of Public Administration and Governance.

54. Ali N (2008) Factors Affecting Overall Job Satisfaction and Turnover Intention. Journal of Managerial Sciences.

55. Armstrong M (2006) A Handbook of Human Resource Management Practice ( $7^{\text {th }}$ edn.), Work Study.

56. Aguenza BB, Som APM (2012) Motivational Factors of Employee Retention and Engagement in Organizations. International Journal of Advances in Management and Economics 1: 88-95.

57. Ahmad FM, Zin MZM, Nor MRM, Sakat AA, Naim AAASA (2012) The Relationship Between Job Satisfaction and Turnover Intention. Am J Appl Sci 9: $1518-1526$.

58. Alamdar H, Muhammad A (2014) Impact of Job Satisfaction on Employee Turnover: An Empirical Study of Autonomous Medical Institutions of Pakistan. Journal of International Studies 7: 122-132.

59. Lee CC (2012) A Study on Factors Affecting Turnover Intention of Hotel Employees. Asian Economic and Financial Review 2: 866-875.

60. Daly JC, Dee JR (2006) Greener Pastures: Faculty Turnover Intent in Urban Public Universities. Journal of Higher Education 77: 776-803.

61. Dockel A, Basson JS, Coetzee M (2003) The Effect of Retention Factors on Organizational Commitment: An Investigation of High Technology Employees. SA Journal of Human Resource Management.

62. Leonard K (2018) Personnel v/s Human Resource Management (4 ${ }^{\text {th }}$ edn.), Universal Book Stall; New Delhi.

63. Girma A (2013) Assessment of Factors Affecting Turnover Intention among Nurses Working at Governmental Health Care Institutions in East Gojjam, Amhara Region, Ethiopia 2013. American Journal of Nursing Science 4: 107-112.

64. Ibrahim IY, Kassa RN, Tasisa GG (2017) Academic Staff Turnover Intention in Madda Walabu University, Bale Zone, South-East Ethiopia. International Journal of Higher Education.

65. Saeed I, Waseem M, Sikander S, Rizwan M (2014) The Relationship of Turnover Intention With Job Satisfaction, Job Performance, Leader Member Exchange, Emotional Intelligence and Organizational Commitment. International Journal of Learning \& Development.

66. Kean NGC (2015) Determinants of Employee Turnover in Manufacturing Company. Master in Human Resource Management: University Utara Malaysia.

67. Khan SA (2013) The Factors Affecting Employee Turnover in an Organization: The Case of Overseas Pakistanis Foundation. African Journal of Business Management 8: 25-34.

68. Sewwandi DVS, Perere GDN Dr (2016) The Impact of Job Stress on Turnover Intention: A Study of Reputed Apparel Firm in Srilanka. International HR Conference.
69. Malik ME, Danish RQ, Munir Y (2011) Employee's Turnover Intentions: Is this HR Failure or Employee's Better Employment Opportunity? International Conference on Innovation, Management and Service.

70. Mizanur R, Feroz I (2013) A Comprehensive Relationship Between Job Satisfaction and Turnover Intention of Private Commercial Bank Employees' in Bangladesh. Int J Sci Res.

71. Mrope G, Bangi I (2014) Examining the Influence of Management Practice and Attitudes on Employee Turnover: A Case of Kibaha District Council. The International Journal of Business \& Management.

72. Muhammad BS (2016) Impact of Perceived Job Autonomy on Turnover Intention in Sales \& Marketing Managers of Services Industry: Moderating Role of Procedural and Distributive Justice. Sci Int 28: 2881-2896.

73. Mulu BH (2014) Factors Affecting Academic Staff Turnover Intentions and the Moderating Effect of Gender, Impact. International Journal of Research in Business Management 2: 57-70.

74. Nasrin A, Hojat D (2013) The Relationship of Job Stress with Turnover Intention and Job Performance: Moderating Role of OBSE. Procedia Soc Behav Sci 84 706-710.

75. Neal JG (1998) Employee Turnover and the Exit Interview. Library Trends Summer.

76. Rizwan M, Arshad MQ, Munir HMA, lqbal F, Hussain A (2014) Determinants of Employees Intention to Leave: A Study from Pakistan. International Journal of Human Resource Studies.

77. Rizwan M, Sajid HHU, Kamran M, Mohsin M, Ali N, et al. (2014) Determinants of Turnover Intentions in Government and Private Employees: An Empirical Study from Pakistan. Journal of Business and Management, pp: 44-51.

78. Shah IA, Zaman K (2010) Measuring Push, Pull and Personal Factors Affecting Turnover Intention: A Case of University Teachers in Pakistan. Review of Economic and Business Studies 3: 167-192.

79. Syed WH, Affan S, Ahmad AA, Ali MR, Akbar M (2015) Causes of Employee Turnover Intention: A Study on Banking Industry of Pakistan. International Interdisciplinary Journal of Scholarly Research.

80. Tariq M, Ramzan M, Raiz A (2013) The Impact of Employee Turnover on the Efficiency of the Organization. Interdisciplinary Journal of Contemporary Research in Business.

81. Tett RP, Meyer JP (1993) Job Satisfaction, Organizational Commitment Turnover Intention, and Turnover - Path Analyses Based on Meta-Analytic Findings. Pers Psychol 46: 259-293.

82. Wafula M, Kerubo OJ, Eunicares L (2017) Factors Affecting Employee Turnover in Hospitality Establishments in Kisii Town, Kenya. Merit Research Journal of Business and Management 5: 30-40.

83. Wei Su H, Li-Tze L, Chiang-Ku F (2011) Turnover Determinants of New Employees in International Hotels. Journal of Service Science and Management 4: 158-164. 